\title{
Response of High Valued Scented Rice to Integrated Nutrient Management under Temperate Agro Climatic Conditions
}

\author{
Nazir A. Teli, M. Anwar Bhat, Ashaq Hussain, M. Ashraf Ahangar*, \\ Manzoor A. Ganaie and Intikhab A. Jehangir \\ Mountain Research Centre for Field Crops (SKUAST Kashmir), Khudwani, \\ Anantnag-192102, India \\ *Corresponding author
}

\section{A B S T R A C T}

Keywords

Scented rice,

Nutrient

management,

Temperate ecology

Article Info

Accepted:

28 February 2018

Available Online:

10 March 2018
A field experiment was conducted at Mountain Research Centre for Field Crops, Khudwani, SKUAST-Kashmir, during Kharif 2012 and 2013 to evaluate the effect of nutrient management on scented rice growth and productivity. Pusa Sugandh-3 recorded significantly higher values of growth parameters, yield attributes and grain yield as compared to Mushkbudj. Application of RFD $+5 \mathrm{t}$ FYM $+2.5 \mathrm{t}$ of Vermicompost $\mathrm{ha}^{-1}$ registered higher values of yield with Pusa sugandh-3, whereas, Mushkbudji recorded highest grain yield at $75 \%$ RFD $+2.5 \mathrm{t}$ of Vermicompost $\mathrm{ha}^{-1}$.

\section{Introduction}

Rice (Oryza sativa L.) crop holds the key for food and nutritional security of the country. In India rice is cultivated in an area of 44 million hectares with a production of 106 million tonnes with average productivity of $2.3 \mathrm{t} \mathrm{ha}^{-1}$ (FAO, 2014). In Jammu and Kashmir rice occupies an important position in the economy and is grown on an area of 274 thousand hectares with annual production of 904 thousand tones and productivity of $3.64 \mathrm{t} \mathrm{ha}^{-1}$ (Anonymous, 2014). Kashmir Division alone has about 158 thousand hectares under rice with a production of 576 thousand tones. In recent years, aromatic rice has been introduced to the global market with great potential to attract rice consumer for its taste and deliciousness, and high price to boost up the economic condition of the rice growers. The productivity of the scented rice is low compared to conventional rice varieties. The local scented rice succumbs to various diseases and furnish poor yield. Muskhkbudji is early maturing and has low cooked kernel length suitable for mid altitudes of the Kashmir region (Parray et al., 2008). To improve the productivity of such scented varieties, more efforts related to production and protection technology are needed. Among 
different agronomic practices nutrient management and selection of particular cultivar to suit a particular climate is important. The present study was conducted with an objective to evaluate the effect organic and inorganic fertilizers on growth and yield of scented rice varieties and to work out economics under temperate agro-climatic conditions.

\section{Materials and Methods}

The experiment was conducted at MRCFC, Khudwani for two consecutive years 20132014 situated in temperate zone of the State Jammu and Kashmir between $34^{\circ} \mathrm{N}$ latitude and $74^{\circ} \mathrm{E}$ longitude at an altitude of 1564 meters above mean sea level. Climatically the experimental site is in mid-altitude temperate zone with an average annual precipitation of $812 \mathrm{~mm}$ (average of past 20 years) most of which is received from December to April in the form of snow and rains. The surface (0-15 $\mathrm{cm})$ soil of experimental site was silty, clay loam in texture with $\mathrm{pH}$ 6.93, organic carbon $0.83 \%$, available nitrogen $238 \mathrm{~kg} / \mathrm{ha}$, available phosphorous $22.5 \mathrm{~kg} / \mathrm{ha}$ and available potassium $160 \mathrm{~kg} / \mathrm{ha}$. The experiment was carried out in Randomized Block Design with three replications. The treatments comprised of two scented rice varieties viz., Pusa Sugandh-3 ( $\left.\mathrm{V}_{1}\right)$, Mushkbudji $\left(\mathrm{V}_{2}\right)$ and eight fertilizer treatments viz., $\mathrm{F}_{0}$ Control, $\mathrm{F}_{1}$ Recommended fertilizer dose (RFD) [60:40:20 N, $\mathrm{P}_{2} \mathrm{O}_{5}, \mathrm{~K}_{2} \mathrm{O}$ $\left.\mathrm{kg} \mathrm{ha}^{-1}\right], \mathrm{F}_{2}$ RFD + 5 tones FYM ha ${ }^{-1}, \mathrm{~F}_{3}$ RFD +2.5 tonnes vermicompost (VC) ha ${ }^{-1,} \mathrm{~F}_{4}, 75 \%$ RFD + 5 tonnes FYM ha ${ }^{-1,} \mathrm{~F}_{5} 75 \%$ RFD + 2.5 tones vermicompost $\mathrm{ha}^{-1}$, F6 RFD + 5 tones $\mathrm{FYM}+2.5$ tones of vermicompost $\mathrm{ha}^{-1} \mathrm{~F}_{7} 75 \%$ $\mathrm{RFD}+5$ tones FYM +2.5 tones of vermicompost $\mathrm{ha}^{-1}$. Thirty one days old seedlings at the rate of three seedlings per hill were transplanted in the plots on the day of uprooting maintaining a spacing of $15 \mathrm{~cm} \times 15$ $\mathrm{cm}$.
All the recommended agronomic practices were followed throughout the growing season. Full recommended dose of phosphorus and potassium in the form of diammonium phosphate and muriate of potash and half of $\mathrm{N}$ through urea at the rate of $60: 40: 20 \mathrm{~kg} \mathrm{~N}$, $\mathrm{P}_{2} \mathrm{O}_{5}$ and $\mathrm{K}_{2} \mathrm{O} \mathrm{ha}^{-1}$, respectively was uniformly applied to each plot as basal as per the treatment. The entire quantity of FYM and vermicompost 0.50 and $0.25 \mathrm{~kg} \mathrm{~m}^{-2}$ was applied as per the treatment before transplanting of rice seedlings. The remaining dose of nitrogen was top dressed in two equal splits at active tillering and panicle initiation stages during both the years.

\section{Results and Discussion}

\section{Growth parameters}

The number of tillers $\mathrm{m}^{-2}$ were recorded significantly higher (450) in Pusa Sugadandh3 at 60 DAT than Mushkabudji (Fig. 2) however the plant height of Pusa Sugadandh3 was significantly lower than Mushkabudji.

The mean Plant height of $104.05 \mathrm{~cm}$ and 115.7 $\mathrm{cm}$ was recorded at harvest with Pusa Sugadandh 3 and Mushkabudji respectively (Fig. 1). Significantly higher number of tillers obtained with Pusa Sugandh-3 compared to Mushkabudji can be attributed to the difference in genotype of variety. These findings are in agreement with Singh et al., (2013).

Application of RFD+5tFYM+2.5t VC ha- ${ }^{1}$ produced significantly taller plants compared to RFD but was statistically at par with $75 \%$ $\mathrm{RFD}+5 \mathrm{t} F Y M+2.5 \mathrm{t} \mathrm{VC} \mathrm{ha}^{-1}$ which could be attributed to quick nourishment from inorganic nutrients at earlier stages and slow and sustained availability of nutrients from FYM and VC at later stages of plant growth. These results are in conformity with Singh and Pal (2011). 
Table.1 Effect of varieties and integrated nutrient management practices on yield attributes of scented rice

\begin{tabular}{|c|c|c|c|c|c|c|c|}
\hline Treatment & $\begin{array}{l}\text { Panicles } \\
/ \mathrm{m}^{2}\end{array}$ & $\begin{array}{c}\text { Panicle } \\
\text { length } \\
\text { (cm) }\end{array}$ & $\begin{array}{c}\text { Panicle } \\
\text { weight } \\
\text { (g) }\end{array}$ & $\begin{array}{l}\text { Spikelets } \\
\text { panicle }^{-1}\end{array}$ & $\begin{array}{l}\text { Filled } \\
\text { grains/ } \\
\text { panicle }\end{array}$ & $\begin{array}{l}\text { Sterility } \\
(\%)\end{array}$ & $\begin{array}{c}\text { 1000- } \\
\text { grain } \\
\text { weight (g) }\end{array}$ \\
\hline \multicolumn{8}{|l|}{ Varieties } \\
\hline Pusa Sugandh-3 & 351 & 21.90 & 3.20 & 113.10 & 76.43 & 34.90 & 24.80 \\
\hline Mushkbudji & 314 & 19.70 & 2.40 & 78.90 & 62.0 & 19.40 & 27.50 \\
\hline $\mathrm{SE}( \pm \mathrm{M})$ & 2.48 & 0.16 & 0.41 & 0.70 & 0.62 & 0.85 & 0.23 \\
\hline$C D(p \leq 0.05)$ & 7.78 & 0.47 & 0.12 & 2.03 & 1.79 & 1.73 & 0.67 \\
\hline \multicolumn{8}{|l|}{$\begin{array}{l}\text { Nutrient management } \\
\text { practices }\end{array}$} \\
\hline Control & 273 & 18.20 & 2.10 & 72.00 & 47.1 & 32.30 & 24.70 \\
\hline $\begin{array}{l}\mathrm{RFD}\left(60: 40: 20 \mathrm{~N}, \mathrm{P}_{2} \mathrm{O}_{5},\right. \\
\left.\mathrm{K}_{2} \mathrm{O} \mathrm{kg} \mathrm{ha}{ }^{-1}\right)\end{array}$ & 308 & 20.50 & 2.60 & 88.20 & 63.9 & 26.30 & 26.00 \\
\hline RFD + 5 t FYM ha ${ }^{-1}$ & 339 & 20.90 & 3.00 & 99.20 & 73.8 & 26.00 & 26.60 \\
\hline $\mathrm{RFD}+2.5 \mathrm{t} \mathrm{VC} \mathrm{ha}^{-1}$ & 344 & 21.00 & 3.00 & 102.10 & 73.9 & 26.10 & 26.40 \\
\hline $75 \%$ RFD + 5 t FYM ha ${ }^{-1}$ & 339 & 21.00 & 3.00 & 99.40 & 71.2 & 24.70 & 26.20 \\
\hline $75 \%$ RFD + $2.5 \mathrm{t} \mathrm{VC} \mathrm{ha}^{-1}$ & 349 & 21.40 & 2.90 & 100.50 & 72.9 & 23.90 & 26.40 \\
\hline $\begin{array}{l}\text { RFD + } 5 \text { t FYM + } 2.5 \mathrm{t} \\
\mathrm{VC} \mathrm{ha}^{-1}\end{array}$ & 354 & 21.90 & 3.00 & 104.00 & 75.2 & 30.10 & 26.20 \\
\hline $\begin{array}{l}75 \% \text { RFD }+5 \text { t FYM + } \\
2.5 \mathrm{t} \mathrm{VC} \mathrm{ha}^{-1}\end{array}$ & 352 & 21.20 & 2.90 & 102.90 & 74.9 & 27.50 & 26.80 \\
\hline $\mathrm{SE}( \pm \mathrm{M})$ & 4.96 & 0.32 & 0.08 & 1.40 & 1.24 & 1.20 & 0.46 \\
\hline $\mathrm{CD}(\mathrm{p} \leq 0.05)$ & 14.32 & 0.93 & 0.24 & 4.06 & 3.58 & 3.46 & NS \\
\hline
\end{tabular}

Table.2 Grain, straw yields and harvest index of scented rice as affected by integrated nutrient management practice

\begin{tabular}{|c|c|c|c|}
\hline Treatment & $\begin{array}{c}\text { Grain yield (t } \\
\left.\text { ha }^{-1}\right)\end{array}$ & $\begin{array}{c}\text { Straw yield (t } \\
\left.\text { ha }^{-1}\right)\end{array}$ & $\begin{array}{c}\text { Harvest index } \\
(\%)\end{array}$ \\
\hline Varieties & 4.58 & 8.60 & 34.28 \\
\hline Pusa Sugandh-3 & 3.81 & 7.85 & 32.72 \\
\hline Mushkbudji & 0.241 & 0.770 & 0.26 \\
\hline SE $( \pm M)$ & 0.695 & 2.25 & 0.76 \\
\hline \multicolumn{4}{|l|}{$\mathrm{CD}(\mathrm{p} \leq 0.05)$} \\
\hline \multicolumn{4}{|l|}{ Nutrient management practices } \\
\hline Control & 2.65 & 6.05 & 30.55 \\
\hline $\operatorname{RFD}\left(60: 40: 20 \mathrm{~N}, \mathrm{P}_{2} \mathrm{O}_{5}, \mathrm{~K}_{2} \mathrm{O} \mathrm{kg} \mathrm{ha}^{-1}\right)$ & 4.08 & 7.72 & 34.61 \\
\hline RFD + 5 t FYM ha-1 & 4.25 & 8.34 & 33.77 \\
\hline $\mathrm{RFD}+2.5 \mathrm{t} \mathrm{VC} \mathrm{ha} \mathrm{g}^{-1}$ & 4.43 & 8.51 & 34.24 \\
\hline $75 \%$ RFD + 5 t FYM ha ${ }^{-1}$ & 4.37 & 8.10 & 35.09 \\
\hline $75 \%$ RFD + $2.5 \mathrm{t} \mathrm{VC} \mathrm{ha-1}$ & 4.43 & 8.14 & 35.30 \\
\hline RFD + 5 t FYM + $2.5 \mathrm{t} \mathrm{VC} \mathrm{ha}^{-1}$ & 4.55 & 9.76 & 31.63 \\
\hline $75 \%$ RFD + 5 t FYM + $2.5 \mathrm{t} \mathrm{VC} \mathrm{ha}^{-1}$ & 4.50 & 9.16 & 32.83 \\
\hline $\mathrm{SE}( \pm \mathrm{M})$ & 0.54 & 1.55 & 0.53 \\
\hline $\mathrm{CD}(\mathrm{p} \leq 0.05)$ & 1.57 & 4.49 & 1.52 \\
\hline
\end{tabular}


Table.3 Relative economics of scented rice as influenced by varieties and integrated nutrient management practices

\begin{tabular}{|c|c|c|c|c|}
\hline Treatments & $\begin{array}{c}\text { Cost of } \\
\text { cultivation } \\
\times \mathbf{1 0}^{\mathbf{3}}\left(\mathbf{F} \mathbf{~ h a}^{\mathbf{- 1}}\right)\end{array}$ & $\begin{array}{c}\text { Gross returns } \\
\times \mathbf{1 0}^{\mathbf{3}}\left(\mathbf{₹} \mathbf{h a}^{-\mathbf{1}}\right)\end{array}$ & $\begin{array}{c}\text { Net returns } \\
\times \mathbf{1 0}^{\mathbf{3}}\left(\mathbf{₹} \mathbf{h a}^{\mathbf{- 1}}\right)\end{array}$ & B: C ratio \\
\hline $\mathbf{V}_{\mathbf{I}} \mathbf{F}_{\mathbf{0}}$ & 44.1 & 160.0 & 115.9 & 2.63 \\
\hline $\mathbf{V}_{\mathbf{I}} \mathbf{F}_{\mathbf{1}}$ & 47.4 & 241.7 & 194.3 & 4.10 \\
\hline $\mathbf{V}_{\mathbf{1}} \mathbf{F}_{\mathbf{2}}$ & 59.9 & 250.9 & 191.0 & 3.19 \\
\hline $\mathbf{V}_{\mathbf{1}} \mathbf{F}_{\mathbf{3}}$ & 72.4 & 255.6 & 183.2 & 2.54 \\
\hline $\mathbf{V}_{\mathbf{1}} \mathbf{F}_{\mathbf{4}}$ & 59.1 & 257.3 & 198.2 & 3.35 \\
\hline $\mathbf{V}_{\mathbf{1}} \mathbf{F}_{\mathbf{5}}$ & 71.6 & 255.0 & 183.3 & 2.56 \\
\hline $\mathbf{V}_{\mathbf{1}} \mathbf{F}_{\mathbf{6}}$ & 84.9 & 289.6 & 204.7 & 2.41 \\
\hline $\mathbf{V}_{\mathbf{1}} \mathbf{F}_{\mathbf{7}}$ & 84.1 & 281.0 & 196.9 & 2.34 \\
\hline $\mathbf{V}_{\mathbf{2}} \mathbf{F}_{\mathbf{0}}$ & 47.3 & 174.7 & 127.32 & 2.69 \\
\hline $\mathbf{V}_{\mathbf{2}} \mathbf{F}_{\mathbf{1}}$ & 50.6 & 246.3 & 195.7 & 3.87 \\
\hline $\mathbf{V}_{\mathbf{2}} \mathbf{F}_{\mathbf{2}}$ & 63.1 & 262.6 & 199.5 & 3.16 \\
\hline $\mathbf{V}_{\mathbf{2}} \mathbf{F}_{\mathbf{3}}$ & 75.6 & 275.1 & 199.5 & 2.64 \\
\hline $\mathbf{V}_{\mathbf{2}} \mathbf{F}_{\mathbf{4}}$ & 62.3 & 263.1 & 200.8 & 3.22 \\
\hline $\mathbf{V}_{\mathbf{2}} \mathbf{F}_{\mathbf{5}}$ & 74.8 & 272.1 & 197.3 & 2.60 \\
\hline $\mathbf{V}_{\mathbf{2}} \mathbf{F}_{\mathbf{6}}$ & 88.1 & 267.5 & 179.4 & 2.04 \\
\hline $\mathbf{V}_{\mathbf{2}} \mathbf{F}_{\mathbf{7}}$ & 87.3 & 264.6 & 177.3 & 2.03 \\
\hline & & & & \\
\hline
\end{tabular}

Fig.1 Plant height of scented rice at different growth stages as affected by varieties

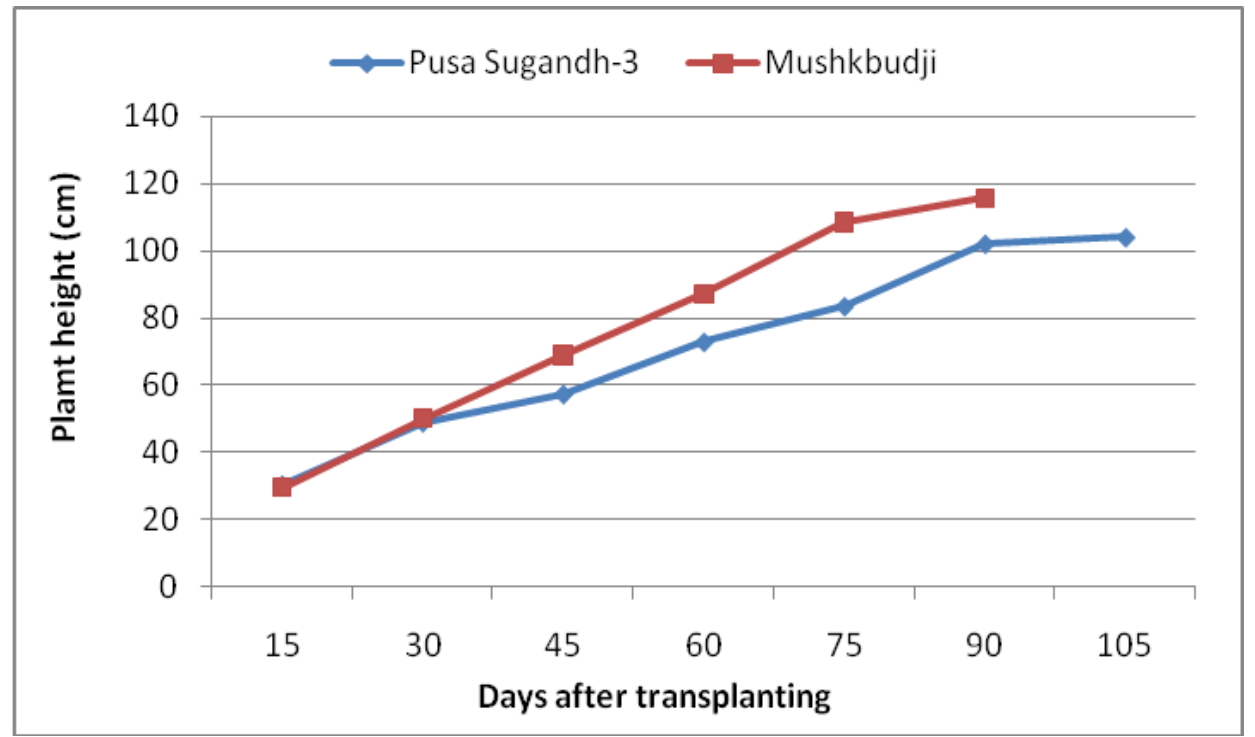


Fig.2 Tiller count of scented rice at different growth stages as affected by varieties

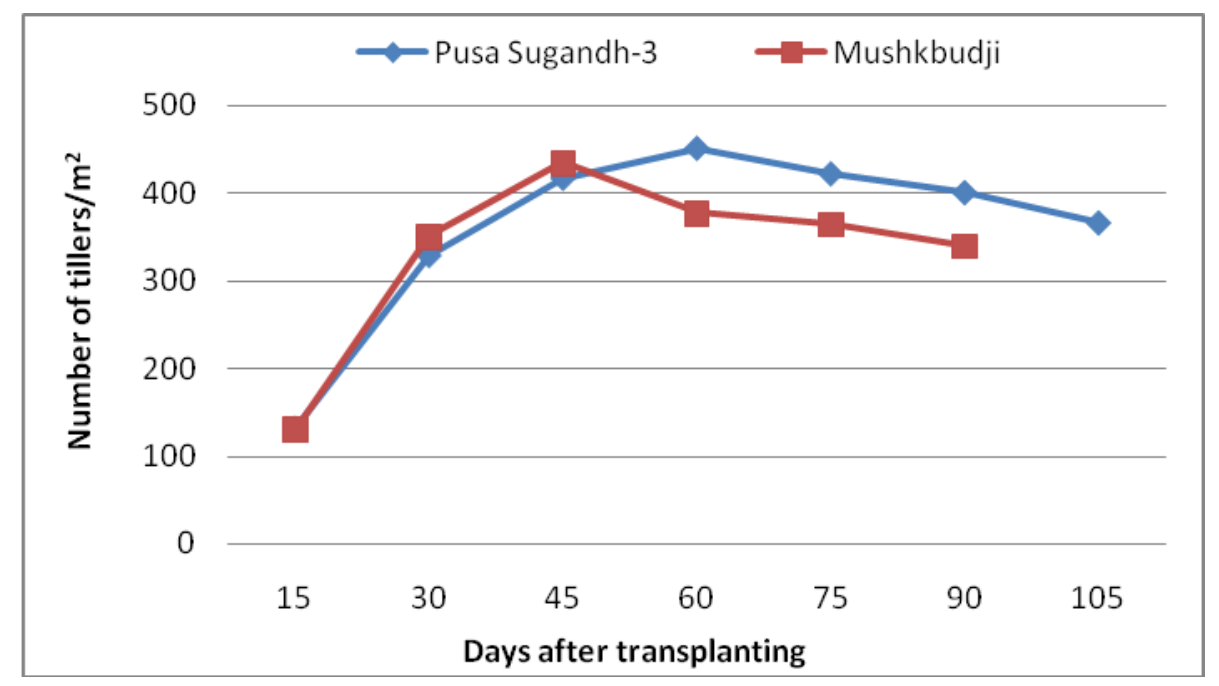

The significantly higher number of tillers can be attributed to better availability of nutrients owing to balanced supply (Safder et al., 2013).

\section{Yield attributes and yield}

Pusa Sugandh-3 recorded significantly higher number of panicles $\mathrm{m}^{-2}$, panicle length, panicle weight, filled grains panicle ${ }^{-1}$, spikelets panicle ${ }^{-1}$ and sterility compared to Mushkbudji (Table 1). However, 1000-grain weight was significantly higher in Mushkbudji. Significant variation among rice cultivars with regard to yield attributes might be due to its genetic makeup and tillers $\mathrm{m}^{-2}$. Yadav and Meena (2014), reported variation in yield contributing characters of different rice cultivars. Pusa Sugandh-3 recorded significantly higher grain and straw yield than Mushkbudji (Table 2) owing to the higher values of all yield attributes. Concurrence findings were observed by Shwetha and Narajan (2012), Singh et al., (2010), Virdia and Mehta (2009).

Application of nutrients brought significantly higher values with respect to higher number panicles $\mathrm{m}^{2}$, grain and straw yield and higher values of test weight though the results were not significant. Application of RFD $+5 \mathrm{t}$ $\mathrm{FYM}+2.5 \mathrm{t} \mathrm{VC} \mathrm{ha}^{-1}$ registered significantly higher number of panicles, with an increase of 12.45 and $23.35 \%$ over RFD and control respectively but at par 75\% RFD + $5 \mathrm{t} \mathrm{FYM} \mathrm{+}$ $2.5 \mathrm{t} \mathrm{VC} \mathrm{ha} a^{-1}$. The results were attributed due to more uptake and utilization of nutrients. Roy et al., (2013) recorded yield attributes under recommended dose of nitrogen through inorganic fertilizers statistically at par $75 \%$ RDN through inorganic and $25 \%$ by organics. Grain yield is a function of growth and yield attributing parameters. Pusa Sugandh-3 had significantly dwarfed plants, more panicles $\mathrm{m}^{-}$ ${ }^{2}$, longer and heavier panicles and higher filled grains panicle ${ }^{-1}$ than Muskbudji. Higher values of all yield attributes gave an advantage to Pusa Sugandh-3 which recorded significantly higher grain and straw yield than Mushkbudji. Such type of findings were also observed by Yadav and Meena (2014); Singh et al., (2013); Safadar et al., (2013) and Manjunath et al., (2012). Marked effect of integrated nutrient management was noticed on grain and straw yield during both the years. Data averaged over two years showed that application of RFD + 5 t FYM $+2.5 \mathrm{t} \mathrm{VC}$ $\mathrm{ha}^{-1}$ registered significantly higher grain yield than other treatments. All the integrated nutrient management practices also produced 
higher grain yield compared to RFD. Higher grain yield with integrated treatments (application of FYM or VC along with RFD) could be ascribed due to the constant availability of nutrients that resulted in significant increase in yield attributing components. This indicated that when organics applied with recommended dose of fertilizer either in whole amount or partly helps in slow release of major and micro nutrients which have catalytic role in photosynthate assimilation and translocation of metabolites from source (leaf) to sink (seed). The increase in grain yield due to the combined use of inorganic and organic manures (FYM and VC) has earlier reported by Lungmauna et al., (2013) and Singh et al., (2012).

\section{Economics}

The highest cost of ₹88 thousand was incurred on the cultivation of Mushkbudji with higher fertility level of RFD + 5 t FYM $+2.5 \mathrm{t} \mathrm{VC} \mathrm{ha}{ }^{-1}$,while the lowest of ₹ 44 thousand was incurred for the cultivation of Pusa Sugandh-3 without fertilizer. Among the varieties Pusa Sugandh-3 recorded higher gross returns, net returns and $\mathrm{B}: \mathrm{C}$ ratio due to higher grain yield and less cost of cultivation (Table 3). Moreover Pusa Sugandh-3 gave higher net returns at higher fertility levels, whereas Mushkbudji registered higher net returns in the treatment receiving comparatively lower fertility levels.

\section{References}

Anonymous, 2014. Directorate of Economics and Statistics, J\&K Government, Srinagar, pp 89-119

FAO, 2004. FAO stat Production Statistics. Food and Agriculture Organization, Rome; 9 http//:www.fao.stat.fao org/p.pagel=567/ancor.
Lungmuana, M. Ghosh and Patra, P. K. 2013. Effect of integrated nutrient Management on available phosphorus influencing grain and straw yield of rice (CV.IR-30) in an Alfisol. Journal of Crop and Weed 9(1):89-93.

Manjunath, B. L., R.R. Verma, R. Ramesh, and Singh, N. P. 2012. Evaluation of varieties and local manorial sources for organic rice (Oryza sativa) production. Indian Journal of Agronomy 57(3): 241244.

Parray, G. A., A. B. Shikari, M. A. Ganaie, and Hussaini, A. 2008. Local aromatic rice cultivars of north Himalayas present status and future strategies for their sustainable improvement. Crop Research 36: 380-381.

Roy, R., K. Singh, S. Singh, and Singh, A. 2013. Integrated nutrient management in rice (Oryza sativa). Indian Journal of Agronomy 58(2): 203-207.

Safadar, M. E., I. R. Noorka, A. Tanveer, S. A. Tariq and Rouf, S. 2013. Growth and yield of advanced breeding lines of Medium Grain Rice as influenced by Different transplanting Dates. The Journal of Animal and Plant Sciences 23(1): 227-231.

Senthivelu, M. and Surya Prabha, A. C. 2007.Influence of integrated nutrient management practices on drymatter production yield and N P K uptake of wet seeded rice. The Asian Journal of Soil Science 2 (1): 45-50.

Shwetha, S. and Narayana, J. 2012. Influence of vermicompost on growth and yield of paddy (Oryza sativa) variety KMP-101. Research Journal of Agricultural Science 3(1): 036-039.

Singh, D. K., G. Singh, S. Gupta, M. Arora, and Verma, S. 2012. Yield sustainability and quality of Basmati rice as influenced by conventional, organic and integrated modes of cultivation. Oryza 49(2):102-107. 
Singh, K. K., Y. V. Singh, and Sharma, S. K. 2010. Influence of biofertilizers and urea application on grain yield and quality attributes in rice (Oryza sativa L.) cultivars. Journal of Soil and Water Conservation 9(4):271-276.

Singh, N., O. V. S., Thenua, D. Kumar and Tyagi, V.K. 2013. Root growth, yield and NPK uptake of rice (Oryza sativa L.) varieties grown by system of rice intensification with varying plant geometry and weed management practices. Annals of Agricultural Research, New Series 34(1): 26-35.

Singh, S. P. and Pal, M. S. 2011. Effect of integrated nutrient management on productivity, quality, nutrient uptake and economics of mustard (Brassica juncea). Indian Journal of Agronomy 56(4): 381-384.

Virdia, H. M. and Mehta, H. D. 2009. Integrated nutrient management in transplanted rice (Oryza sativa L.). Journal of Rice Research 2(2): 99-104.

\section{How to cite this article:}

Gurumurthy, B.R. and Naik, M.K. 2018. Techniques for Determination of Vitamin B 6 , Vitamin $\mathrm{C}$ and Variability in Areca Nut (Areca catechu) Samples of Karnataka, India. Int.J.Curr.Microbiol.App.Sci. 7(03): 3496-3502. doi: https://doi.org/10.20546/ijcmas.2018.703.402 